\title{
Evaluation of Different Blended Fertilizer on Maize Yield and Soil Properties Under Acidic Soil at Southwest Ethiopia
}

\author{
Ewnetu Teshale*, Jafar Dawud, Tolossa Ameyu \\ Ethiopian Institute of Agricultural Research, Jimma Agricultural Research Center, Jimma, Ethiopia \\ *Corresponding Author: Ewnetu Teshale., Ethiopian Institute of Agricultural Research, Jimma \\ Agricultural Research Center, Jimma, Ethiopia
}

\begin{abstract}
In Ethiopia, reports have indicated that about $43 \%$ of arable land is affected by soil acidity though its severity extent varies. A field experiment was conducted to evaluate of the effect of balanced fertilization on maize crop under limed and unlimed soil condition at Jimma and Illubabor zone of different districts from 20152017 cropping years. The experiment was laid out in split plot design with three replications main plot as lime and unlimed, sub plot as blended fertilizer (untreated control, Recommended NP, Formula 2 (NPSB), F4 (NPSZnB), F4 M (NPSZnB) and F5 (NPKSZnB) was used in the investigation. Initial and after harvest soil data was taken. The result revealed that most of the treatments mean grain yield $\mathrm{kg} / \mathrm{ha}$ near to similar However, The maximum mean maize grain weight 6341.8 and $8635.2 \mathrm{~kg} / \mathrm{ha}$ was recorded from Formula 2 (NPSB) at Jimma, Kera and Tiro, respectively. At Mettu (Нигити) closely related yield was recorded at all plot except the control plot. The maximum grain yield $5693.4 \mathrm{~kg} / \mathrm{ha}$ was recorded from F5 (NPKSZnB). Application of lime also indicated yield increment as compared with unlimed plots. Economic analysis also indicated that Formula 2 (NPSB) gave the maximum benefits next to recommended NP fertilizers. In general, recommended NP and Formula 2 (NPSB) Blended fertilizer under limed conditions gave the maximum mean maize grain yield and enhances soil $\mathrm{pH}$ and available soil phosphorus and also economically feasible as compared with other treatments.
\end{abstract}

Keywords: blended fertilizer, grain yield, maize, soil

\section{INTRODUCTION}

Crop yield on acid soils are frequently reduced to $50 \%$ and can be reduced to zero in severe cases (Cornelissen, 2018). In Ethiopia, maize had been growing from moisture stress areas to high rainfall areas and from lowlands to highlands of the country. Among cereals, maize is the first and second crop in terms of volume of production and area coverage followed next to teff (Eragrostis tef/Zucc./Trotter) (CSA, 2017). Maize is one of the important cereal crops in the world's agricultural economy both as food for human and feed for animals. Because of its higher yield potential compared to other cereals, it is called as "Queen of cereals" (FAO, 2013). Although different reports have also indicated that there is significant soil acidity coverage in Ethiopia (Wassie and Shiferaw, 2009). Soil acidity is a complex of numerous factors involving nutrient/element deficiencies and toxicities, low activity of beneficial microorganisms and reduced plant root growth that limit nutrient and water uptake (Fageria and Baligar, 2002). It was the most important soil factors which affect plant growth and ultimately limit crop production and profitability (Fageria, 2009) and its problems are common in all regions where precipitation is high enough to leach appreciable amounts of exchangeable bases from the soil surface (Achalu, et al., 2012). There are considerable evidence in literature that showed at soil $\mathrm{pH}<5.5$ affects the growth of crops due to high concentration of aluminum (Al) and manganese $(\mathrm{Mn})$, and deficiency of $\mathrm{P}$, nitrogen $(\mathrm{N})$, sulfur (S) and other nutrients (Abreha, 2013). In Ethiopia, reports have indicated that about $43 \%$ of arable land is affected by soil acidity though its severity extent varies. Huge portion of soil acidity is found in south western and western part of the country where annual precipitation is high so as to leach basic cations out of rooting zone (Achalu et al., 2012). However, to overcome soil acidity problem by using liming material and organic amendments are the primary options to raises soil $\mathrm{pH}$ at which crops vigorously grow properly (Poozesh et al., 2010). Moreover, liming contributes appreciable amount of basic secondary macronutrients like $\mathrm{Ca}^{+2}$ and $\mathrm{Mg}^{+2}$ which are essential for plants (Fageria and Nascente, 2014). A standard application of $100 \mathrm{Kg}$ urea and $100 \mathrm{Kg}$ DAP has conventionally been recommended across the country for most crops and soil types. However, this 
recommendation fails to address the current fertility status of the soil and specific crop needs. Urea, $\mathrm{CO}$ $\left(\mathrm{NH}_{4}\right)_{2}$ and DAP $(\mathrm{NH} 4)_{2} \mathrm{PO}_{4}$ are acid forming fertilizers (Eyasu, 2019). Therefore, an issue of balanced fertilization and liming was immerged for improving acid soil productivity. However, the blended fertilizer recommendation on acid soils under un-limed and limed conditions so far not done in the area. Therefore, this trial was conducted with the objective to investigate the effect of blended fertilizers on acid soil productivity under limed condition.

\section{MATERIALS AND Methods}

\subsection{General Description of the Study Area}

The study was conducted at Jimma (Kersa and Tiro Afeta woredas) and Ilubabore Metu (Hurumu woreda) zones, in South Western Ethiopia. The woredas are located at a distance of 310- $587 \mathrm{~km}$, south western of the capital Addis Ababa. Geographically, the woredas lies between latitudes of $7^{0} 42^{\prime \prime} \mathrm{N}, 7^{0} 49^{\prime \prime} \mathrm{N}$ and $8^{0}$ 03 " $\mathrm{N}$ longitudes of $37^{0} 33^{\prime \prime} \mathrm{E}, 37^{\circ} 33^{\prime \prime} \mathrm{E}$ and $30^{\circ \prime}$ ' $\mathrm{E}$ with altitudes ranging from 1777,1765 and1550 meters above sea level, respectively. The mean annual temperature of the woredas ranges from $17.6-25^{\circ} \mathrm{C}$ and the average annual rainfall is about $13200-1300 \mathrm{~mm}$ per year. The dominant soils of the area were reported (Paulos, 1994) as Nitisols which are sesquioxidic and moderately to strongly acidic.

\subsection{Soil Sampling and Analysis}

A soil sample was taken from the top soil (0 to $20 \mathrm{~cm}$ ) from Jimma (Tiro), Jimma (Kersa) and Metu (Hurumu) experimental site before planting and after harvesting of the crops. Then, the soil was air dried, ground and passed through a $2 \mathrm{~mm}$ sieve and analyzed for selected chemical properties according to standard laboratory procedures at Jimma Agricultural Research Center. Soil pH was measured potentiometrically with a digital $\mathrm{pH}$ meter 1:2.5 soils to water ratio. Organic carbon was determined by the modified Walkley and Black procedure wet combustion methods, Total nitrogen was determined by the Kjeldahl digestion and distillation procedure Available $\mathrm{P}$ was extracted by the Bray-II method and quantified using spectrophotometer (wave length of $880 \mathrm{\eta m}$ ) colorimetrically using vanadomolybedate as an indicator. Total exchangeable acidity was determined by saturating the soil samples with $1 \mathrm{M} \mathrm{KCl}$ solution and titrated with $0.02 \mathrm{M} \mathrm{NaOH}$.

\subsection{Experimental Design and Procedures}

Field experiment was conducted with split plot design with 3 replications on maize crop for three cropping seasons on acid soils of Ilubabore and Jima zone of south-western Ethiopia. Before commencement of the experiment, experimental field was characterized for selected soil physical and chemical properties, soil samples were collected from $0-20 \mathrm{~cm}$ depth for initial determination of soil fertility parameters. Thereafter, and to evaluate changes in soil as a result of applied treatments, soils were sampled at harvest. Maize BH661 varieties were used in the investigation and seeds were sown by $80 \mathrm{~cm} \times 50 \mathrm{~cm}$ spacing. The experiment was laid out in split plot design with three replications main plot as lime and unlime, sub plot as blended fertilizer formula (untreated control, Recommended NP, Formula 2 (NPSB), F4 (NPSZnB), F4 M (NPSZnB) and F5 (NPKSZnB) was used in the investigation. The recommended urea was used as the source of N. Application of urea was made in two splits, half at sowing and half at knee height; while the entire blended fertilizer formula was applied at sowing in band.

\subsection{Determination of Lime Rate}

The limed treatments comprise full doses of lime used based on Ex.ac, $\mathrm{Kg} \mathrm{ha}^{-1}$ at all sites. In 2015 lime $(\mathrm{CaCO} 3)$ was hand broadcasted and thoroughly mixed with soils one month before planting of the test crop. In 2016 and 2017 cropping season lime was used as residual effect.

\subsection{Data Analysis}

Data collected from the crop and soil were subjected to analysis of variance using SAS software packages and mean separation was done using LSD (Gomez and Gomez, 1984) at 5\% probability level.

\section{RESULTS AND DISCUSSION}

\subsection{Initial Soil Sample of the Study Area}

The soil samples were analyzed for $\mathrm{pH}$, available $\mathrm{P}$, exchangeable acidity, total $\mathrm{N}$, and OM. Initially the soils of the experimental site were strongly acidic $(\mathrm{pH}=4.5,4.03$ and 4.46) at Tiro, Kersa and 
Evaluation of Different Blended Fertilizer on Maize Yield and Soil Properties Under Acidic Soil at Southwest Ethiopia

Hurumu respectively according to soil classification based on soil pH (Eyasu, 2016); and low in available Phosphorus level (Table 1).

Table1. Some soil chemical properties of initial soils before lime application

\begin{tabular}{|c|c|c|c|c|c|}
\hline Location & $\mathrm{pH}_{\mathrm{W}}$ & Avai.P(ppm) & $\% \mathrm{TN}$ & OC \% & $\begin{array}{c}\text { Ex.Ac. } \\
\left(\mathrm{cmol}^{-1}\right)\end{array}$ \\
\hline Jimma (Tiro) & 4.03 & 1.74 & 0.182 & 2.012 & 1.30 \\
\hline Jimma (Kersa) & 4.5 & 1.62 & 0.146 & 2.150 & 1.20 \\
\hline Metu (Hurumu) & 4.46 & 2.03 & 0.122 & 1.24 & 3.14 \\
\hline
\end{tabular}

\subsection{Some Selected Soil Physic-Chemical Property After Harvesting At Jimma}

The initial soil result at the three locations Tiro, Kersa and Metu showed that strong acid, low available Phosphorus, medium total $\mathrm{N}$ and high in exchangeable acidity (Table 1). While after harvesting the soil analyzed result revealed that limed plots soil properties such as, $\mathrm{pH}$, total $\mathrm{N}$, available phosphorus were increased and in contrary the exchangeable acidity was reduced as compared with control and unlimed plots. This was due to the neutralizing values of lime which reduce the activity $\mathrm{Al}^{3+}$ and $\mathrm{H}^{+}$and enhances the availability of other essential nutrients (Fig 1,2 and 3)

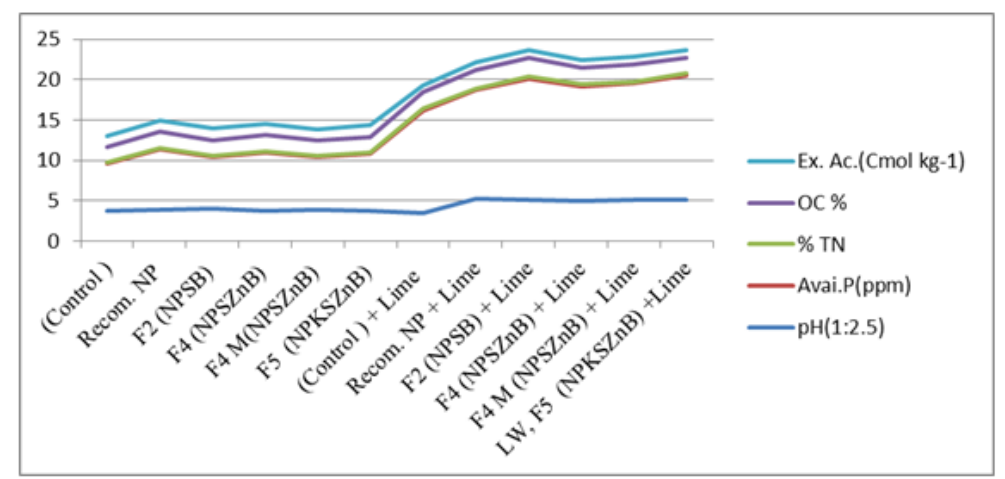

Fig1. Mean of some soil chemical properties of soils of testing site of Jimma (Tiro Afeta) after on limed soil during harvesting.

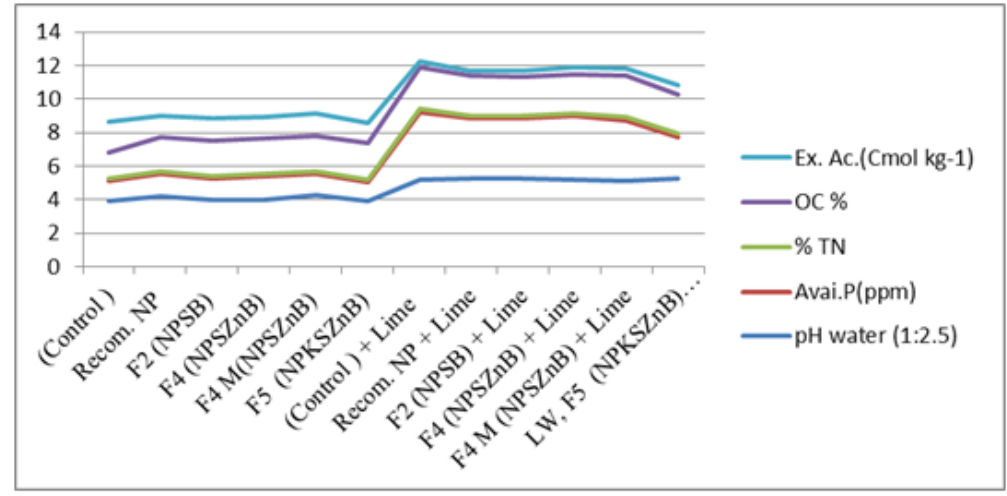

Fig2. Mean of some soil chemical properties of soils of testing site of Jimma (Kersa) before and after lime application

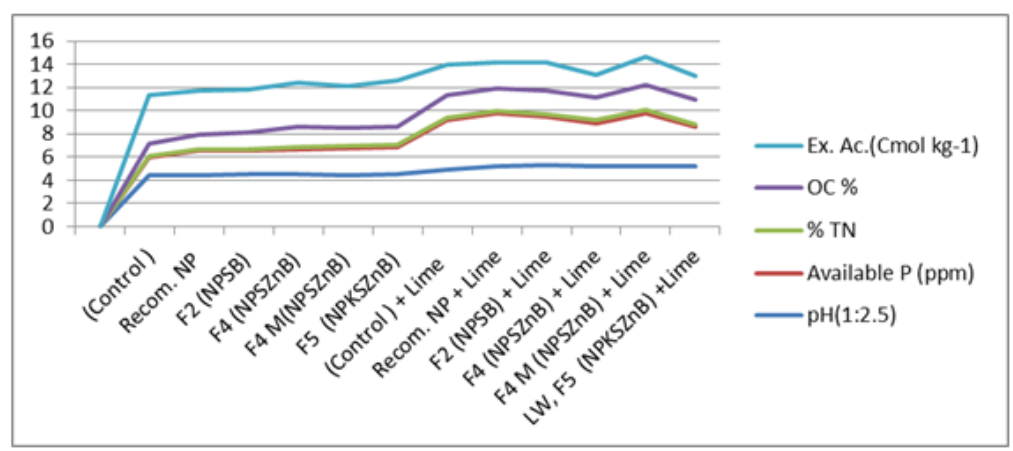

Fig3. Mean of some chemical properties of soils test tasting site of Metu (Hurumu) after harvesting 


\subsection{Effects of Blended Fertilizer on Maize Crop Yield Under Limed and Unlimed Conditions}

The trial was well established at all locations but the higher yield observed at Tiro Afeta than Kersa and Metu. As compared to the other yield of Metu location less due to strong acidity of soil. In all locations and seasons negative control treatment had shown lowest yield and no interaction between lime and blended fertilizer in all seasons. The effect of recommended fertilizer increase yield or highly significant in most locations and seasons similar to balanced blended fertilizer formulas (Table 2) but less yield difference observed as compared to some balanced blended fertilizer formulas. (Table 1) Significant result observed among fertilizers in all seasons. However, there was no interaction between lime and blended fertilizer in all seasons. Blended fertilizer significantly $(\mathrm{P}<0.05)$ influenced yield of maize crop in all seasons at Jimma (Kersa) and Tiro Afata locations. The result revealed that over years mean cropping season at Jimma (Kersa) and Tiro Afata location, formula 2 (NPSB) gave significantly highest grain yield of Maize( 6341 and $8635.2 \mathrm{Kg} / \mathrm{ha}$ ), respectively. Similarly at Metu (Hurumu) site the maximum yield $5693.4 \mathrm{~kg} / \mathrm{ha}$ was recorded from F5 (NPKSZnB) While the lowest values at 3 locations $2688,4193.3$ and $3142.4 \mathrm{~kg} / \mathrm{ha}$ was recorded from the control treatment at Kersa, Tiro and Hurumu respectively (Table 1 ).

The effects of lime over years on grain yield indicated that statically significant difference among the treatments at Jimma (Kersa) and Metu (Hurumu). The result revealed that limed treatments gave the highest grain yield of Maize 5826.4 and $5499.3 \mathrm{~kg} / \mathrm{ha}$ over unlimed 5377 and $4659.7 \mathrm{~kg} / \mathrm{ha}$ (Table 2). On the other hand at Jimma effects of lime on the grain yield statically not significance among the treatments but, the maximum grain yield was recorded as compared with Jimma (Kersa) and Metu (Hurumu) sites.

Yield increment over the year observed between lime and un lime main plot at Jima (Kersa) and Metu (Hurumu) was 8 and 18\%. Maize grain yield increment over control (un limed), also yield increment over the year observed between control and fertilizer treatments, by recommended fertilizer $116 \%$ maize grain yield increment over control recorded. However, the new fertilizer formulas shown greater $\%$ yields increment over the control (Table 2). This may be from the new blended fertilizer content is improved. From the new blended fertilizer formulas 2 NPSB Shown 136 and $106 \%$ yield increment over the control and recommended fertilizer at Jimma (Kersa) and Jimma(Tiro). Similarly, F5 (NPKSZnB) gave the maximum yield increments $81 \%$ as compared the control treatments.

Table2. Effect of blended fertilizer and limed on over years (2015-2017) \% Maize grain yield (kgha $\left.{ }^{-1}\right)$ increment over control

\begin{tabular}{|c|c|c|c|c|c|c|}
\hline Treatment & \multicolumn{2}{|r|}{ Kersa } & \multicolumn{2}{|r|}{ Tiro } & \multicolumn{2}{|r|}{ Metu } \\
\hline Lime level & $\begin{array}{c}\text { Over year } \\
\text { mean }\end{array}$ & $\begin{array}{c}\% \mathrm{GY} \mathrm{Kg} \\
\text { Increment } \\
\text { over } \\
\text { control } \\
\end{array}$ & $\begin{array}{c}\text { Over year } \\
\text { mean }\end{array}$ & $\begin{array}{c}\% \mathrm{GY} \mathrm{Kg} \\
\text { Increment } \\
\text { over control }\end{array}$ & $\begin{array}{c}\text { Over year } \\
\text { mean }\end{array}$ & $\begin{array}{c}\% \mathrm{GY} \mathrm{Kg} \\
\text { Increment } \\
\text { over } \\
\text { control } \\
\end{array}$ \\
\hline L0 ( Un limed) & $5377.0 \mathrm{~b}$ & & 7618.4 & & $4659.7 \mathrm{~b}$ & \\
\hline L1 ( Limed) & $5826.4 \mathrm{a}$ & 8 & 7672.0 & 1 & $5499.3 \mathrm{a}$ & 18 \\
\hline $\mathrm{LSD}_{0.05}$ & 235.66 & & NS & & 418.15 & \\
\hline Blended fertilizer & & & & & & \\
\hline Control (No fert.) & $2688.2 b$ & & $4193.3 c$ & & $3142.4 b$ & \\
\hline Recomm.NP & $5943.6 a$ & 116 & $8271.5 \mathrm{ab}$ & 97 & $5295.3 \mathrm{a}$ & 69 \\
\hline Formula 2 (NPSB) & $6341.8 \mathrm{a}$ & 136 & $8635.2 \mathrm{a}$ & 106 & $5507.1 \mathrm{a}$ & 75 \\
\hline F4 (NPSZnB) & $6294.8 \mathrm{a}$ & 135 & $8509.3 \mathrm{ab}$ & 103 & $5411.8 \mathrm{a}$ & 72 \\
\hline F4 M (NPSZnB) & $6199.8 \mathrm{a}$ & 131 & $8073.9 \mathrm{~b}$ & 96 & $5426.8 \mathrm{a}$ & 73 \\
\hline F5 (NPKSZnB) & $6142.0 \mathrm{a}$ & 128 & $8187.9 \mathrm{ab}$ & 95 & $5693.4 \mathrm{a}$ & 81 \\
\hline $\mathbf{L S D}_{0.05}$ & 408.18 & & 503.7 & & 724.26 & \\
\hline CV\% & 9.91 & & 10.92 & & 21.37 & \\
\hline
\end{tabular}

\subsection{Partial Budget Analysis}

Partial budget analysis was made to compare economic feasibility of applied lime and fertilizers. The results indicated that higher marginal rate of return was obtained by applying recommended NP follow by NPSB fertilizer with lime treated plots at 3 locations. Moreover, the yields of recorded from NPSB fertilizer without lime were marginally high (Fig 4, 5). 


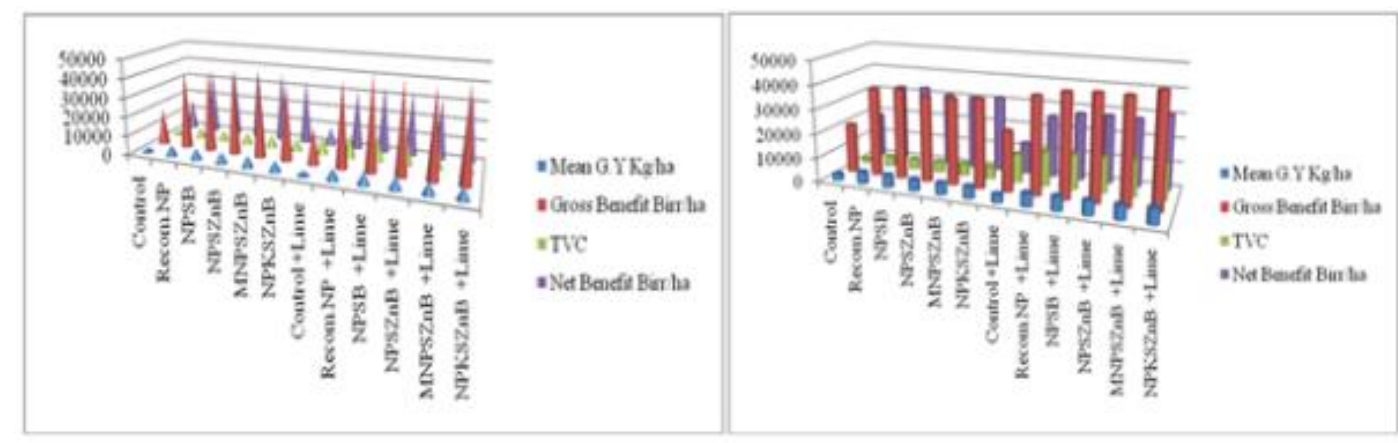

(a)

(b)

Fig4. Partial budget analysis for the mean grain yield of maize at Kersa (a) and Tiro Afata (b)

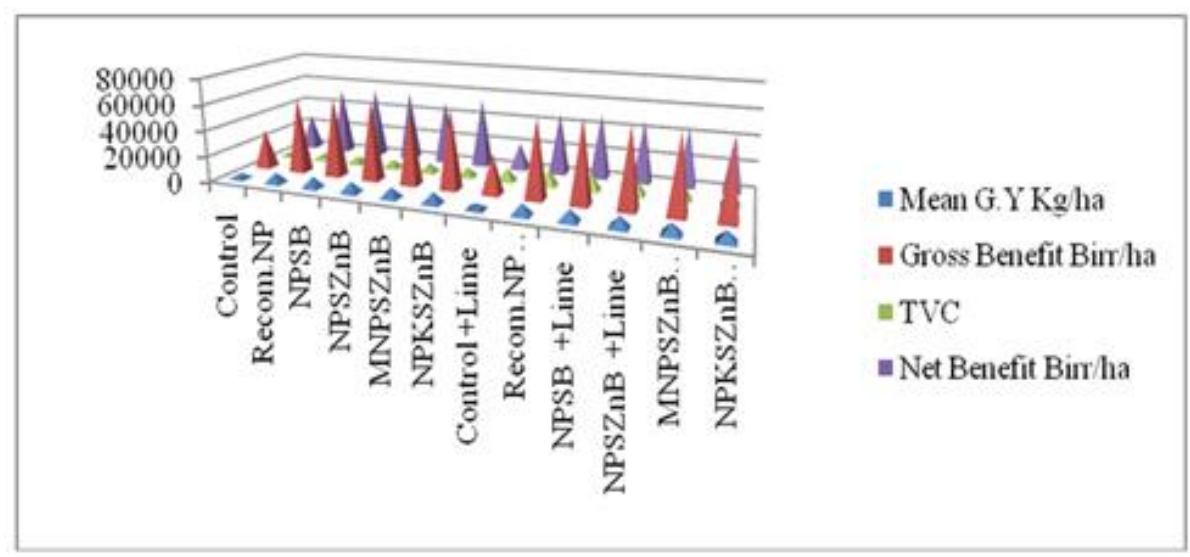

Fig5. Partial budget analysis for the mean grain yield of maize at Metu

Whereas NPSB blended fertilizers indicted that economic feasibility and beside improves the availability of the nutrient to the maize crop growth next to recommended NP fertilizer.

\section{CONCLUSION}

Blended fertilizer recommendation on acid soils under un-limed and limed conditions so far not done. Therefore, it is now found pertinent to determine blended fertilizer levels under limed conditions. To overcome these problems the activity of lime and blended fertilizer trialed was conducted at 3 locations Jimma (Kersa and Tiro Afata) and Metu (Hurum). The result reviled that applications of Formula 2 (NPSB), Blended fertilizers under limed conditions gave the mean maximum maize grain yield at all locations. In addition NP fertilizer recommended rate with limed plots gave the maximum economic return as compared to the other treatments similarly soil $\mathrm{pH}$ and available phosphorus enhanced and contrary exchangeable acidity was declined which affects the growth and yield of the crops. Economic analysis also indicated that Formula 2 (NPSB) gave the maximum benefits next to recommended NP fertilizers

\section{REFERENCES}

[1] Abreha Kidanemariam, Heluf Gebrekidan, Tekalign Mamo and Kindie Tesfaye. 2013. Wheat crop response to liming materials and $\mathrm{N}$ and $\mathrm{P}$ fertilizers in acidic soils of Tsegede highlands, northern Ethiopia Agriculture, Journal of Forestry and Fisheries 2(3): 126-135.

[2] Achalu Chimdi, Heluf Gebrekidan, Kibebew Kibret and Abi Tadesse, 2012, Status of selected physicochemical properties of soils under different land use systems of Western Oromia, Ethiopia. Journal of Biodiversity and Environmental Sciences, 2(3): 57-71.

[3] Central Statistical Agency (CSA). 2017. Report on Area and Production of Major Crops (Vol. 1). Addis Ababa, Ethiopia.118p.

[4] Cornelissen, G., Nurida, N. L., Hale, S. E., Martinsen, V., Silvani, L., \& Mulder, J. (2018). Fading positive effect of biochar on crop yield and soil acidity during five growth seasons in an Indonesian Ultisol. Science of the Total Environment, 634, 561-568.

[5] Eyasu, E., Okoth, P. F., \& Smaling, E. M. A. (2019). Explaining bread wheat (Triticum aestivum) yield differences by soil properties and fertilizer rates in the highlands of Ethiopia. Geoderma, 339, 126-133. 
[6] Fageria, N. K., \& Nascente, A. S. (2014). Management of soil acidity of South American soils for sustainable crop production. In Advances in agronomy (Vol. 128, pp. 221-275). Academic Press.

[7] Fageria, N. K., V. C. Baligar, and R. B. Clark. 2002. Micronutrients in crop production. Adv. Agron. 77:185268.

[8] FAO., 2013. FAO Statistical Yearbook: World Food and Agriculture. FAO.

[9] Paulos Dubale, 1994. Mineral Fertilizer of Coffee in Ethiopia. Institute of Agricultural Research, Addis Ababa, Ethiopia. 105p.

[10] Poozesh, V., Castillon, P., Cruz, P., \& Bertoni, G. (2010). Re-evaluation of the liming-fertilization interaction in grasslands on poor and acid soils. Grass and Forage Science, 65(2), 260-272.

[11] Wassie, Haile, Shiferaw Boke. 2009. Mitigation of soil acidity and fertility decline challenges for sustainable livelihood improvement: research findings from southern region of Ethiopia and its policy implications. Awassa Agricultural Research Institute

Citation: Ewnetu Teshale, Jafar Dawud, Tolossa Ameyu, “Evaluation of Different Blended Fertilizer on Maize Yield and Soil Properties Under Acidic Soil at Southwest Ethiopia”, International Journal of Forestry and Horticulture, 6(4), pp. 18-23. DOI: https:// doi.org/10.20431/2454-9487.0604003

Copyright: () 2020 Authors, this is an open-access article distributed under the terms of the Creative Commons Attribution License, which permits unrestricted use, distribution, and reproduction in any medium, provided the original author and source are credited. 